\title{
How authentic leadership promotes individual knowledge sharing: viewing from the lens of COR theory
}

\author{
Huy Phuong TRAN \\ National Economics University Hanoi, Vietnam \\ phuongth@neu.edu.vn
}

\begin{abstract}
Fostering knowledge sharing has been one of the most vital tasks for organizations in the knowledge based economy. Thus, investigating the antecedents of knowledge sharing behavior is of great interest to both academics and practitioners. The impact of leadership on knowledge sharing has been reported in the literature. However, the direct and indirect impacts of authentic leadership on knowledge sharing is under-researched. Furthermore, because knowledge is an individual resource, knowledge sharing can be investigated in the light of the conservation of resource theory. This study applies conservation of resource theory to examine the influence of authentic leadership on knowledge sharing with relational psychological contract and organizational based self-esteem as mediators. Data collected from survey using questionnaire were used to test the hypotheses in a quantitative research design. Structural equation modelling (SEM) techniques are applied for data analysis. The results showed that authentic leadership positively and significantly influence individual knowledge sharing. Furthermore, relational psychological contract and organizational based selfesteem have been found to mediate the above relationship. Discussion of research findings, theoretical and practical implications are also detailed. Finally, the study outlines limitations of research and provides directions for further knowledge sharing studies.
\end{abstract}

Keywords: authentic leadership, knowledge sharing, conservation of resource theory (COR), relational psychological contract organizational based self-esteem (OBSE).

\section{Introduction}

The movement from industry-based economy toward knowledge based economy has highlighted the role of knowledge management in organizations (Kim, Li and Yun, 2016). Knowledge sharing (KS) is regarded as a crucial element of knowledge management system and has received a great deal of research efforts and practical attentions during the past few decades (Stenius, Hankonen, Ravaja, and Haukkala, 2016; Ali, Selvam, Paris, and Gunesakaran, 2019). Although employees' sharing of knowledge is highly desirable by organizations, it could be seen as a threat to the individual employee who shares the knowledge. In fact, researchers found evidences that knowledge hoarding is more like the rule, while KS is the exception (Davenport and Prusak, 1998; Dong, Gia Liem and Grossman, 2010). Because of the "knowledge is power" notion, knowledge sharing may be seen as giving out the power of the knowledge providers. Furthermore, sharing knowledge can be seen as a risky behavior because it may result in loss of competitive advantage over peers (Holste and Fields, 2009; Kim et al., 2016). In order to foster knowledge sharing, organization must compensate for this risk by providing rewards or supports (Titi Amayah, 2013; Ali et al., 2019). Among sources of social support, leadership is the most important because leaders are organizational agents and key decision-makers who behaviors strongly influence individual motivation and actions of knowledge sharing (Srivastava et al., 2006). Wang and Noe (2010) reviewed literature on knowledge sharing and suggested that leadership characteristics may affect knowledge sharing and called for more research in the topic. A number of studies have investigated the impact of leadership on knowledge sharing. Xue, Bradley, and Liang (2011), and Srivastava et al. (2006), for instance, found that an empowering leader who provides guidance to followers, treats them fairly, and recognizes their inputs as valuable fosters knowledge sharing in teams. On the other hand, Kim et al. (2016) provided evidence that an abusive leader who displays hostile verbal and nonverbal 
behaviors hinder KS among employees. Other research suggested that a leader with integrity, trustworthiness, and justice is more likely to promote knowledge sharing (Ma, Cheng, Ribbens, and Zhou, 2013; Han, Seo, Yoon, and Yoon, 2016). Recently, research attention has focused on exploring the impact of authentic leadership (AL) on employee outcomes. Authentic leadership aims to foster positive working environment based on leaders' moral characters and concerns for others, as well as congruency between ethical values and actions (Hannah, Avolio and Walumbwa, 2011). Despite evidences that support the positive impacts of AL on various desirable employee outcomes (Gardner, Cogliser, Davis, and Dickens, 2011), research on the link between AL and KS is still limited (Edú-Valsania, Moriano and Molero, 2015; Li, Wu and Lin, 2017). The current study investigates the influence of authentic leadership on individual knowledge sharing.

Knowledge is long recognized as a resource that helps the organizations to create and maintain sustainable competitive advantages in the current knowledge-based economy (Nonaka and Takeuchi, 1995; Ahmad and Karim, 2019). At the individual level, knowledge is also a resource which constitutes competitive advantage to each employee in the workplace (Kim et al., 2016). Knowledge sharing involves employees' making available their own knowledge for the achievement of goals, solving problems, developing new ideas, or improving procedures (Wang and Noe, 2010; Ali et al., 2019). Knowledge sharing, however, may represent a dilemma in situations when firm members share knowledge resources without knowing the about the use or production of knowledge by others (Frost and Morner, 2010). In viewing knowledge as an individual resource, Conservation of Resource (COR) theory provides a theoretical framework to understand individual knowledge sharing behaviors. COR theory (Hobfoll, 1989) proposes that people strive to retain, protect, and build resources and that what is threatening to them is the potential or actual loss of these valued resources. COR theory also identifies four kinds of resource including objects, conditions, personal characteristics and energies. Objects are valued because of their physical aspects or secondary status they offer. A home is valued because it provides shelter, while a diamond has increased value as it proves status. Objects are linked to socioeconomic status, with the latter is related to stress resistance. Conditions, such as marriage, tenure, and seniority are resources to the extent that they are valued and sought after. Research suggested that living with someone or being married (a condition) is helpful in dealing with stress (Henderson, Byrne, and Duncan-Jones, 1981). The third type of resource, personal characteristics, refers to personal traits and skills that aid stress resistance. Mastery, intimacy, received social support, and discomfort in seeking support, for example, have been found to contribute to stress resistance (Hobfoll, 1985). The final kind of resource, energies, encompasses such resources as time, money, and knowledge. These resources are important mainly because they are helpful in the acquisition of other kinds of resources. The current study examines the influence of authentic leadership on knowledge sharing in light of the COR theory.

Because knowledge sharing is a self-motivated behavior, employee's motivation plays a vital role in KS process (Ibragimova, 2007). Therefore, the impact of organizational context such as leadership on KS is likely to be transferred by a number of intermediary variables. Furthermore, despite the potential impacts of AL on fostering positive employee attitudes and behaviors, there is still a lack of empirical evidence to validate these relationships (Gardner et al., 2011). This calls for further research to explore potential mediating variables in the authentic leadership-employee outcomes relationships (Ribeiro, Duarte, Filipe, and de Oliveira, 2019). The current study responds to these calls and contributes to the literature by examining the mediating roles of relational psychological contract and organizational based self-esteem on the relationship between authentic leadership and KS. 


\section{Literature review}

\section{Knowledge and knowledge sharing}

Although knowledge is a well known and powerful concept, there is no clear universal definition of knowledge (Bolisani and Bratianu, 2018). Nonaka defines knowledge as being "justified true belief", and consider knowledge as "a dynamic human process of justifying personal beliefs as part of an aspiration for the truth" (Nonaka, 1994, p.15). However, practically knowledge can be referred to as information processed by individuals including ideas, facts, expertise, and judgments relevant for individual, team, and organizational performance (Wang and Noe, 2010, p.117). Knowledge is classified into explicit knowledge and tacit knowledge (Nonaka and Takeuchi, 1995). Explicit knowledge is part of knowledge which can be express and explained easily in words and numbers, is easily codified into databases and thus can be easily transmitted to others (Henttonen et al., 2016; Fullwood, Rowley, and McLean, 2018). In contrast, tacit knowledge is embedded in personal experience, and difficult to reduce to writing (Nonaka and Konno, 1998; Holste and Fields, 2010; Martins and Martins, 2011).

Knowledge sharing is the process of transferring task information and know-how to other organizational members in a manner suitable for problems solving or implementation of organisation policies or procedures (Wang and Noe, 2010, Okah et al., 2011). Knowledge sharing is generally voluntary in nature and can be considered extra-role behaviors (Akram, Lei, Haider, Hussain, and Puig, 2017; Bao, Xu, and Zhang, 2015). Therefore, in order to foster knowledge sharing, a number of prerequisite conditions have been proposed such as management support and contextual factors (Bock, Zmud, Kim, and Lee, 2005). Among these factors, the influence of leadership on knowledge sharing has been documented in previous studies (Wang and Noe 2010; Asrar-ul-Haq and Anwar, 2016).

\section{Authentic leadership}

Authentic leadership is defined as "a pattern of leader behavior that draws upon and promotes both positive psychological capacities and a positive ethical climate, to foster greater selfawareness, an internalized moral perspective, balanced processing of information and relational transparency on the part of leaders working with followers, fostering positive selfdevelopment" (Walumbwa, Avolio, Gardner, Wernsing, and Peterson, 2008, p.94). Literature has explored and identified several components of authentic leadership namely selfawareness, relational transparency, internalized moral perspective and balanced processing (Walumba et al., 2008; Avolio, Gardner, Walumbwa, Luthans, and May, 2004; Gardner, Avolio, Luthans, May, and Walumbwa, 2005). Self-awareness refers to the extent that leaders clearly understand their strengths and weaknesses as well as other aspects of themselves. It also includes the leaders' understanding about the impacts they may have from others' perspectives. Many authors believe that self-awareness is the most important component of authentic leadership (Chaudhary and Panda, 2018; Avolio et al., 2004). Relational transparency relates to the extent to which a leader openly and truly shares information, thoughts and real feelings with the absence of displaying distorted self (Avolio et al., 2004; Gill and Caza, 2018). Balanced processing manifests in the leader's thorough and careful analysis of all relevant data before making a decision in an unbiased manner (Kernis, 2003; Oh, Cho and Lim, 2018). Finally, internalized moral perspective measures the consistency between a leader's actions and his or her moral norms and values (Walumbwa et al., 2008). Leaders with an internalized moral perspective behave in ways that act on the values, preferences, and needs of a collective group (Oh et al., 2018).

\section{Relational psychological contract}


Psychological contract describes the formation of individual perceptions by employees regarding what is owed by themselves and the organization (Rousseau, 1989). Psychological contract can be classified into a continuum of transactional and relational contract (McNeil, 1985; Rousseau, 1989, 1995). Transactional contract involves short-term financial relationships involving specific exchanges such as pay and work conditions. Issues such as trust, attachment and commitment are not incorporated in transactional contract because of limited time frame (Knights and Kennedy, 2005). Relational contract, on the other hand, is based on socio or emotional and non-monetary exchanges which do not cover any specific time frame (Rousseau, 1990).

\section{Organizational based self esteem}

Pierce, Gardner, Cummings, and Dunham (1989) defined organizational based self-esteem (OBSE) as "the degree to which organizational members believe that they can satisfy their needs by participating in roles within the context of an organization" (p. 625). Employees with high level OBSE see themselves as important, meaningful, effectual and worthwhile within their organization. OBSE has been found to link with a host of employee positive outcomes such as intention to remain (Lin, Jang, and Roberts, 2018), positive organizational behaviors (Pan, Quin, and Gao, 2014), coworker and team satisfaction, and perceived team member effectiveness (Gardner, and Pierce, 2016), organizational commitment (Tang, Singer and Roberts, 2000; Van Dyne and Pierce, 2004) and employee well-being (Pierce, Gardner, and Crowley, 2016).

\section{Hypothesis development}

\section{Influence of Authentic leadership on knowledge sharing}

According to COR theory, stress is defined "as a reaction to the environment in which there is: (a) the threat of a net loss of resources; (b) the net loss of resources; and (c) a lack of resource gain following the investment of resources" (Hobfoll, 1989, p. 516). COR theory also suggests that when confronted with stress, individuals attempt to minimize net loss of resources and when not confronted with stress, people strive to develop resource surpluses in order to offset the possibility of future loss (Hobfoll, 1989, p.517). Therefore, in order for an individual to share their knowledge resource, he or she must perceive a lack of current net loss of resource or possibility of future resource surplus associated with such actions.

Authentic leadership may create these conditions in the following ways. First, an authentic leader, who is aware of their strength and weaknesses, is more likely to appreciate knowledge shared to him and other organizational members including explicit knowledge such as formula or information as well as tacit knowledge such as know-how or personal experience. Because an authentic leader understands the impacts of his actions on followers, this leader tends to acknowledge or publicly recognize the knowledge contributors. The provision of such status provides condition, another type of resource identified by COR theory, which can be used to replace and offset net loss of resource. Second, relational transparency associated with an authentic leader enables him to openly and truly share information, thoughts and real feelings without manipulation (Avolio et al., 2004; Gill and Caza, 2018). Information provided by an authentic leader may represent "justified true belief", i.e. knowledge, to the recipients. This knowledge can also be of high value to the individuals because it helps them solve their leader-member related problems and achieve goals. Thus, working under an authentic leader creates the opportunities to gain knowledge and minimize net loss. Research has found that as a role model, a leader who shares knowledge would encourage others to do the same (Eppler and Sukowski, 2000). Third, an authentic leader, instead of distorting, exaggerating, or ignoring information, would 
thoroughly and carefully analyze all relevant data before making decisions. Knowledge contributors, who observe that their knowledge is appreciated by the leader, may develop the feelings of being valued by the organization. These feelings are condition resource that can compensate for the loss of knowledge resource. A balanced-processing leader also provides frank and honest feedback to employees to help them refine, develop or rethink their ideas. Reevaluating resources is proposed as a strategy that people can use to combat their sense of resource loss (Hobfoll, 1989). Following the feedback from an authentic leader, the individuals may reevaluate the knowledge resources which they share in comparison with the knowledge which they gain from such feedback. The reevaluation may result in a more positive perception of loss. Finally, guided by internal ethical standards, an authentic leader strives to serve collective interests (Avolio and Gardner, 2005; Walumbwa et al., 2008). Acknowledging the importance of knowledge sharing to the firm's operation, this leader is likely to foster knowledge sharing among other organizational members (Edú-Valsania et al., 2016). When other members also share their knowledge, perception of net loss and threat of net loss is reduced, fostering knowledge sharing. Based on the above reasoning, it is hypothesized that:

\section{H1: Authentic leadership is positively associated with knowledge sharing}

\section{The mediating role of Relational Psychological contract}

AL increases the balanced information treatment and the levels of transparency and relational work between leaders and followers (Gardner et al., 2005; Zhang and Bartol, 2010). Subsequently, it promotes the positive self-development of followers (Semedo, Coelho, and Ribeiro, 2017). Furthermore, the relationship between AL and employee trust in leader has been confirmed in previous research (Engelbrecht, Heine, \& Mahembe, 2014; Javed et al., 2018). In addition, Nielsen, Eid, Mearns, and Larsson (2013) suggested that AL is negatively related to risk perception and positively associated with ratings of safety climate. In psychological contract theory, Rousseau and McLean Parks (1993) argued that contract types differ in terms of focus, time-frame, stability, scope and tangibility. Relational contract is based on less tangible rewards such as trust, respect and loyalty and is open-ended with indefinite duration (De Meuse, Bergmann, and Lester, 2001). Rousseau and McLean Parks (1993) suggested that transactional contract can be formed as a trial run before a longer term contract is formulated. Transactional contract serves as a risk minimizing strategy in selecting a long-term agreement. Therefore, it can be inferred that the employees form relational contract with the organization when they believe in the long-term and win-win cooperation. Because AL enhances the environment of trust, promotes the development of employees, creates psychological safety, and reduces risk, we can expect that under the supervision of an authentic leader, employees tend to form relational psychological contract.

H2: Authentic leadership is positively associated with relational psychological contract.

Relational psychological contract involves mainly emotional terms, and long-term commitments by both parties (Rousseau and McLean Parks, 1993). Employees with relation contracts are willing to contribute their commitment and loyalty to the organization in exchange for their professional career development. A relational contract can create feelings of affective involvement or attachment in the employees, and can engage the employer to providing more than purely remunerative support to the individuals with investments like training, personal and career development, and provision of job security (Gupta, Agarwal, Samaria, Sarda, and Bucha, 2012). Such commitments by the organization can be seen as resource gain (objects, conditions and energies) and, according to the rule of reciprocity, the individuals are willing to devote their contribution by sharing their knowledge resources without experiencing net resource loss or fear of net resource loss. If the individuals invest 
their knowledge resource in expectation of net resource gain, they are more likely to do so in a long-term indefinite relationship (i.e. relational contract) than in a short-term definite timeframe transactional psychological contract. Therefore, we can expect that relational psychological contract is positively related to knowledge sharing. Due to the fact that knowledge sharing is mainly self-motivated, the influence of leadership on knowledge sharing behaviors need to be transferred to states of mind that motivate the individuals to share knowledge (Ibragimova, 2007). It is therefore hypothesized that:

H3: Relational psychological contract mediates the positive impact of authentic leadership on knowledge sharing.

\section{The mediating impact of organizational based self esteem}

OBSE involves an individual's evaluations of his or her self-worth within the workplace (Pierce et al., 1989). Research has suggested that interpersonal relationships and organizational culture transmit the messages of value from the organization to the employees, and thus, are important predictors of OBSE (Korman, 1970; Baumeister, 1999). Among interpersonal relationships in organization, leader-member quality has been examined as a correlate of OBSE. Pierce et al. (1989) found that the perception of managerial respect is positively related to OBSE. Similarly, Heck, Bedeian, and Day (2005) reported a positive and significant relationship between the quality of the leader-member exchange relationship and OBSE. Norman, Gardner and Pierce (2015) suggested that the influence of manager on employee OBSE can be exerted by three mechanisms. First, leadership styles may shape work environment structures. Highly structured work environments tend to reduce OBSE (Pierce and Gardner, 2004) while social systems that allow for more autonomy and influence are more likely to enhance OBSE (Elloy, 2005). Therefore, leadership styles that provide opportunities for employee participation in decision-making, promote self-direction and selfcontrol, are associated with higher OBSE (Norman et al., 2015). Authentic leaders are transparent and consistent in decision making and in interactions with followers. They encourage followers to voice diverse viewpoints and incorporate those viewpoints into their decision-making process (Avolio et al., 2009). Authentic leaders also objectively analyze all the important data before making decision, making room for employee's participation in such decision-making process (Oh, Cho and Lim, 2018). Thus, authentic leadership is expected to enhance OBSE.

Second, Norman et al. (2015) argued that messages received from significant others such as leaders, managers, or co-workers within the workplace are antecedents of OBSE. There are evidences that managers who provide opportunities for followers to have an impact on the organization would enhance the way employees view themselves within organizations (De Cremer, van Knippenberg, van Knippenberg, Mullenders, and Stinglhamber, 2005). On the other hand, controlling and directive styles may be interpreted by employees as if they are not competent and trustworthy and thus lower OBSE (Wang, Huang, Chu, and Wang, 2010). Authentic leadership aims to foster positive working environment based on leaders' moral characters and concerns for others, as well as congruency between ethical values and actions (Hannah, Avolio and Walumbwa, 2011). Authentic leaders influence their followers through developmental interactions empowerment, identification and promotion of followers' potentials (George, 2003; Luthans and Avolio, 2009). Therefore, authentic leadership is likely to promote employee's OBSE.

Third, Norman et al. (2015) proposed that employees' experiences of success or failure, and their attributions of causality for those experiences influence self-esteem. If employees can attribute themselves for past successes, they will develop a higher level of OBSE. On the other hand, if the employees can only blame themselves for failures, they tend to experience lower level of self-esteem (Korman, 1970). By providing conditions for 
successful implementation of tasks, managers can positively foster employee's OBSE (Norman et al., 2015). Authentic leaders clearly understand their strengths and weaknesses, express their true thoughts and feelings, and match actions with words (Walumbwa et al., 2008). In case of failures, authentic leaders are willing to take responsibility for their role in such failures. Thorough and careful analysis of all relevant data enables authentic leaders to make unbiased decisions. Therefore, authentic leaders credit individuals for their contributions to the organizational successes and avoid wrongly criticize employees for failures. Leaders with an internalized moral perspective behave in ways that act on the values, preferences, and needs of a collective group. Such leaders are willing to supply employees with necessary resources for the implementation of organizational tasks. Therefore, authentic leadership may lead to higher level of OBSE. Previous research has confirmed the mediating roles of OBSE on the relationship between authentic leadership and subordinate's outcomes (Liang, 2017). Therefore, it is hypothesized that:

\section{H4: Authentic leadership is positively related to OBSE.}

Extant literature explored numerous outcomes of Organization-based self-esteem ranging from motivation to in-role and extra-role performance (Pierce and Gardner, 2004). OBSE is defined as the degree to which an individual believes him/herself to be capable, significant, and worthy as an organizational member (Pierce et al., 1989). OBSE measures the degree to which employees believe that they can satisfy their needs by taking roles within the organization. Therefore, individual with high level of OBSE have a sense of satisfied needs. According to COR theory, conditions are resources to the extent that they are valued and sought after (Hobfoll, 1989, p. 517). Marriage, tenure, and seniority are examples of conditions. Being a significant and worthy member in an organization, therefore, is a conditions resource. High level of OBSE may represent resource surplus that enables individuals to share their knowledge without fear of net resource loss. In addition, individuals high in OBSE can also share knowledge as a form of resource investment in expectation of future net resource gain. The sharing of individual knowledge which contributes to the organization's success will enhance the contributors' value and image within the organization. Because such value and image is sought after by the individuals, these represent resource gain. OBSE has been found to predict organizational citizenship behaviors which may include knowledge sharing (Van Dyne and Pierce, 2004; Chattopadhyay and George, 2001). Bao et al. (2016) also found that OBSE acts as a mediator of the relationship between employees' trust (in the organization, supervisors and peers) and knowledge sharing. Therefore, it is hypothesized that

H5: OBSE mediates the positive impact of authentic leadership on knowledge sharing.

\section{Method}

\section{Data collection}

A survey questionnaire was designed and used to collect data for the current study. Target respondents are employees at three big service companies in Hanoi, Vietnam with a total of 2600 employees. Questionnaires were distributed with permission from the Human Resource departments of the three companies. Emails were sent via institutional email addresses provided by the Human Resource department to all employees. Email reminders were sent after each one week for the period of a month. After one month we obtained a total of 391 returned questionnaires, of which 364 are usable. Women employees accounted for 35\% (127) and men employees covered 75\% (237) of the total sample. Their average age of the respondents was 33.5 and the average tenure at the organization was 8.4 years. 


\section{Measures}

All measures were obtained using a self-administered questionnaire. Responses were scored in a 5-point Likert-type scale ( $1=$ strongly disagree to 5 strongly agree).

Authentic leadership (AL): AL was measured using the 16 items of the AL Questionnaire (ALQ) developed by Walumbwa et al. (2008). The ALQ measures four dimensions: self-awareness, relational transparency, internalized moral perspective, and balanced processing. Sample items include: "My supervisor seeks feedback to improve interactions with others" (self-awareness), "My supervisor says exactly what he or she means" (relational transparency), "My supervisor demonstrates beliefs that are consistent with actions" (Internalized Moral Perspective), and "My supervisor listens carefully to different points of view before coming to conclusions" (balanced processing). Reliability of the scale in this study is .943 .

Knowledge sharing behaviors (KS): Five items developed by Hsu and Chang (2014) were used to measure individual knowledge sharing behaviors. One item was "I frequently contribute my knowledge to other people within my department". The reliability coefficient of the scale was 0.94. The scale was also validated in prior studies such as (Ali et al., 2019) with the reliability coefficient of 0.78 .

Relational psychological contract (RPC) was measured by a 9-item scale extracted from the 18-item scale ( 9 for relational contract and 9 for transactional contract) used by Raja, Johns and Ntalianis (2004). The scale was an abbreviated version of Millward and Hopkins' (1998) 33-item Psychological Contract Scale. Sample items include "I expect to grow in this organization" and "I feel this company reciprocates the effort put in by its employees". Reliability of the scale in this study is .895.

Organization-based self-esteem (OBSE): OBSE was measured using the 10-item Organization-Based Self-Esteem Scale (Pierce et al., 1989). Sample items of this Likert-type scale include "I count in my organization" and "I am taken seriously in my organization". Cronbach's alpha is .739 in the current study.

\section{Results}

\section{Reliability and validity}

The measurement model consisted of four latent variables: AL, RPC, OBSE, and KS. Reliability, Convergent validity and discriminant validity was tested by calculating and comparing composite reliabilities (CR), average variance extracted (AVE), and maximum shared squared variance (MSV).

To test the reliability and validity of the measurement model, the loadings for each item and the composite reliabilities (CR) were examined. Item reliability specifies the correlations of the items with their respective construct which is indicated by the item's loading. Chin (1998) suggests a minimum loading of 0.70 . As reported in Table 1 , the composite reliability values for all latent variables were higher than the cut-off value of 0.70 .

The average variance extracted (AVE) was calculated to examine the convergent validity of the constructs (Fornell and Larcker, 1981). Convergent validity refers to the degree to which scores on one scale correlate with scores on other scales designed to assess the same construct. For convergent validity, AVE should be equal or greater than .50 and lower than Composite Reliability (CR). In other words, the variance explained by the construct should be greater than measurement error and greater than cross-loading. These results in Table 1 indicated that there were no convergent validity issues with the model. All the AVE scores were above the 0.5 threshold and lower than CR (Hair, Black, Babin, Anderson, and Tatham, 2006), thereby indicating the satisfactory convergent validity of the measures. 
For discriminate validity, the maximum shared variance (MSV) and average shared squared variance (ASV) were calculated. Discriminant validity means that the measures of a given construct differ from those of another construct. Discriminant validity is confirmed if average variance extracted (AVE) is greater than maximum shared squared variance (MSV) and average shared squared variance (ASV). All the constructs yielded satisfactory results. The MSV and ASV values found were lower than the AVE, thereby confirming the discriminant validity of the constructs.

Table 1: Correlations and validity

\begin{tabular}{lccccccc}
\hline Variable & CR & AVE & MSV & AL & KS & RPC & OBSE \\
\hline AL & 0.899 & 0.622 & 0.353 & $(0.788)$ & & & \\
KS & 0.907 & 0.608 & 0.396 & $0.464^{*}$ & $(0.779)$ & & \\
RPC & 0.852 & 0.625 & 0.396 & $0.406^{*}$ & $0.389^{*}$ & $(0.790)$ & \\
OBSE & 0.723 & 0.588 & 0.224 & $0.321^{*}$ & $0.205^{*}$ & $0.129^{*}$ & $(0.766)$ \\
\hline
\end{tabular}

Source: Authors' own contribution.

$\mathrm{CR}=$ Composite Reliability, $\mathrm{AVE}=$ Average variance extracted; $\mathrm{MSV}=$ maximum shared squared variance. $\mathrm{N}=$ 364. *: correlations are significant at the .001 level. Diagonals (in parentheses) represent the square root of the average variance extracted.

\section{Common method bias}

Because the data were collected from only one source (i.e. the respondent himself), common-method variance needed to be checked to ensure that the data had no major problem with response bias. The test for checking common-method variance used in this study was Harman's single-factor test, as suggested by (Podsakoff et al., 2003). Common method bias is considered to be a problem if one factor contributing to more than 50 percent of total variance. All 40 items were inserted in a principal component analysis and examining the number of factors extracted from these items. The result indicated that 4 factors were extracted from the unrotated solution. I double-checked the results by forcing the 40 items into one factor. Our analysis with one factor solution suggested that this factor accounts for only 28.46 percent of the total variance. Furthermore, more than 50 percent of the items suffering from poor factor loadings that fell below 0.5. This suggests that common method bias is not a serious problem with this dataset.

\section{Measurement model}

Structural equation modeling through AMOS 22.0 was used to test hypotheses. The maximum likelihood estimation was used to measure the estimation of parameters in the model. The chi-square (CMIN), degree of freedom (df) ratio, goodness of fit index (GFI), Tucker Lewis index (TLI), comparative fit index (CFI) and root mean square error of approximation (RMSEA) were considered to ensure that the model fit the data. The indices show a good fit of the data with measurement model. The CMIN/df (1108/699) value is 1.586, less than the threshold value of 2 (Tabachnick \& Fidell, 2013). A goodness of fit index (GFI) of .921, Tucker Lewis index (TLI) of .907, and Comparative Fit Index (CFI) of .917 were obtained from the data which are higher than the recommended level of $.90(\mathrm{Hu} \&$ Bentler, 1999). Furthermore, the Root Mean Square Error of Approximation (RMSEA) is .40, lower than the threshold of .07 (Steiger, 1990). Finally, the Standardized Root Mean Square Residual (SRMR) is .056, smaller than the suggested value of .08 by Hu and Bentler (1999). Overall, these suggest a good fit for the measurement model.

Table 2: Hypothesis testing

\begin{tabular}{lllll}
\hline Hypothesis & Path & Estimate & P value & Decision \\
\hline $\mathrm{H} 1$ & $\mathrm{AL} \rightarrow \mathrm{KS}$ & .237 & $<.001$ & Supported \\
$\mathrm{H} 2$ & $\mathrm{AL} \rightarrow \mathrm{RPC}$ & .249 & $<.001$ & Supported \\
$\mathrm{H} 3$ & $\mathrm{AL} \rightarrow \mathrm{RPC} \rightarrow \mathrm{KS}$ & .083 & $<.01$ & Partially Supported \\
\hline
\end{tabular}




\begin{tabular}{|c|c|c|c|c|}
\hline $\mathrm{H} 4$ & $\mathrm{AL} \rightarrow \mathrm{OBSE}$ & .240 & $<.01$ & Supported \\
\hline H5 & $\mathrm{AL} \rightarrow \mathrm{OBSE} \rightarrow \mathrm{KS}$ & .067 & $<.01$ & Partially Supported \\
\hline
\end{tabular}

\section{Hypothesis testing}

The hypothesized relationships between the research variables were tested using the structural model. Maximum Likelihood (ML) estimator was used in the current study. In order to obtain robust standard errors of estimates, bootstrapping with 1000 bootstrap samples was utilized. Results show that AL has a positive and significant effect on $\mathrm{KS}$ $(\beta=.237 ; p<.001)$, providing support for hypothesis H1. Similarly, AL also exerts significant impacts on relational psychological contract $(\beta=.249, \mathrm{p}<.001)$, supporting hypothesis $\mathrm{H} 2$. In order to test the mediating effect of relational psychological contract, this study applies the steps proposed by Baron and Kenny (1986). In the first step, AL has been found to significantly influence KS (H1), in the second step, AL was correlated with RPC (H2). Next, RPC significantly affects KS $(\beta=.334, \mathrm{p}<.001)$. Finally, the effect of AL on KS controlling for RPC is still significant, suggesting a partially mediated relationship. In order to obtain a robust estimate of the indirect effect of AL on KS, the myindirect effect add-in estimand for AMOS was used with 2000 bootstrapping samples. The result indicated that the indirect effect $(\beta=.083, p<.01)$ is also significant, indicating a partial mediation model. Therefore, H3 is partially supported.

Similar procedure was done to test the remaining hypothesis. The results showed that AL is positively related to OBSE $(\beta=.240, p<.01)$, supporting Hypothesis H4. OBSE significantly predicts KS $(\beta=.281, p<.001)$, and the indirect effect of AL on KS via OBSE is also positive and significant $(\beta=.067, \mathrm{p}<.01)$. Therefore, H5 is partially supported.

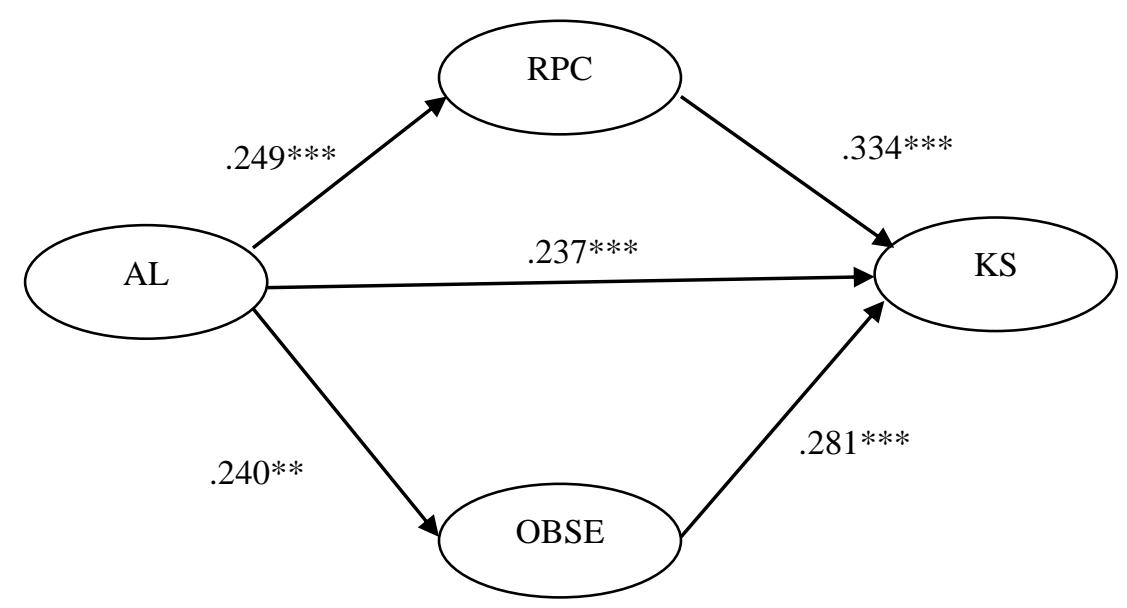

Figure 1: SEM analysis results

Source: Authors' own contribution.

\section{Discussion}

The results confirm the positive impacts of authentic leadership on knowledge individual knowledge sharing. This extends literature on the influence of leadership on knowledge sharing, in which leadership can have both positive and negative influence on knowledge sharing among employees (Wang and Noe, 2010). Leadership styles that promote positive psychological climate such as empowering leadership (Srivastava et al., 2006; Xue et al., 2011), and transformational leadership (Dong, Bartol, Zhang, and Li, 2017; Han et al., 2016) foster knowledge sharing, while controlling leadership (Singh, 2008), and abusive leadership (Kim, et al., 2016) hinders KS. The results confirm that the leadership styles that involve human interaction and encourage participative decision-making processes are important 
determinants of knowledge sharing (Politis, 2001). Authentic leadership encourages KS by fostering a positive working environment based on leaders' moral characters and concerns for others, as well as congruency between ethical values and actions (Hannah, Avolio and Walumbwa, 2011). In view of COR theory, the behaviors of an authentic leader reduce the threat of or actual net resource loss by providing objects or conditions resources in order to compensate for the loss of knowledge resource. Authentic leadership also ensures the future return of resource for the investment of current knowledge resource. Therefore, under the supervision of an authentic leader, employees are willing to share knowledge resource.

The study also specifies the mechanisms in which AL exerts its impacts on KS. Previous knowledge management literature concluded that trust is a vital condition of knowledge sharing while lack of trust hinders KS (Wang and Noe, 2010; Asrar-ul-Haq, and Anwar, 2016). The findings of this study suggest that AL can create an environment of trust and respect, in which employees are willing to contribute their long-term commitment to the organization by forming relational psychological contract. The long-term committed employees are willing to share the knowledge resource as a long-term investment for future net gain of resource.

Authentic leadership positively influences the way an employee evaluates his or her self-worth within the workplace and thereby improves the employee's OBSE. Because the employee wants to be an important and worthy member in the organization, OBSE may represent resource gain. The employee may share knowledge resource in exchange for this gain in resource.

\section{Theoretical Contributions}

This study contributes to the literature on knowledge sharing by studying KS through the lens of the COR theory. COR theory suggests that individuals avoid stress by minimizing net loss of resource or invest resource in expectation of future net resource gain. Knowledge is considered as one kind of resource, and knowledge sharing can be viewed as losing resource. To encourage knowledge sharing in the workplace, the provision of resource replacement or certainty of future resource gain is a necessary condition. AL fosters KS by providing true information, frank and accurate feedback, making good use of knowledge resource, and ensuring return of knowledge and other resource. Second, the current study confirms the influence of relational psychological contract on individual knowledge sharing. According to COR theory (Hobfoll, 1989), when not confronting with stress, the individual employee may invest resource for net future resource gain. A long-term trust based relationship is important for knowledge sharing. Finally, OBSE, a valued and sought after condition can improve knowledge sharing among individuals. This can expand literature on the predictors of individual knowledge sharing beyond environmental factors, individual characteristics and motivational factors (Wang and Noe, 2010).

\section{Practical implications}

The study suggests that in order to foster knowledge sharing in the workplace, it is necessary to provide resource so that the knowledge contributors do not experience net loss. The managers can provide resource replacement by sharing their true thoughts and experience, providing information and feedback (knowledge resource), offering physical rewards (object resource), and awarding status such as knowledge contributor (condition resource) in order to promote KS in their organizations.

\section{Limitation}

The first limitation of this study lies in its sampling method. Data were collected from a limited numbers of firms, which may not be representative of the entire population. Next, 
data were collected only from one source, which may be prone to common method bias. Finally, the cross-sectional research design does not allow firm conclusions about the direct, mediating and moderating impacts among the study's variables. Future research needs to examine possible relationships using longitudinal studies.

\section{Conclusion}

In closing, the primary goal of this study was to examine how authentic leadership affects individual knowledge sharing. With data collected from individuals, the results showed that AL influences KS directly and indirectly through the mediating impact of relational psychological contract and organizational based self-esteem. Based on COR, the study concludes that AL fosters knowledge sharing by reducing perception of net resource loss and increasing expectancy of future resource gain.

\section{References}

Ahmad, F., \& Karim, M. (2019). Impacts of knowledge sharing: a review and directions for future research. Journal of Workplace Learning, 31(3), 207-230.

Akram, T., Lei., S, Haider, M.J., Husain, S.T., \& Puig, L.C.M. (2017). The effect of organizational justice on knowledge sharing: An empirical evidence from the Chinese telecommunication sector. Journal of Innovation and Knowledge, 2(3), 134-145.

Ali, A. A., Panneer selvam, D., Paris, L., \& Gunasekaran, A. (2019). Key factors influencing knowledge sharing practices and its relationship with organizational performance within the oil and gas industry. Journal of Knowledge Management, ahead-of-print. doi: 10.1108/JKM-06-2018-0394.

Asrar-ul-Haq, M., \& Anwar, S. (2016). A Systematic Review of Knowledge Management and Knowledge Sharing: Trends, Issues, and Challenges. Cogent Business and Management, 3(1), 1-17.

Avolio, B. J., Gardner, W. L., Walumbwa, F. O., Luthans, F., \& May, D. R. (2004). Unlocking the mask: A look at the process by which authentic leaders impact follower attitudes and behaviors. The Leadership Quarterly, 15(6), 801-823.

Avolio, B. J., Walumbwa, F. O., \& Weber, T. J. (2009). Leadership: Current Theories, Research, and Future Directions. Annual Review of Psychology, 60(2009), 421-449.

Bao, G., Xu, B., \& Zhang, Z. (2016). Employees' trust and their knowledge sharing and integration: the mediating roles of organizational identification and organization-based self-esteem. Knowledge Management Research \& Practice, 14(3), 362-375.

Baron, R. M., \& Kenny, D. A. (1986). The moderator-mediator variable distinction in social psychological research: Conceptual, strategic and statistical considerations. Journal of Personality and Social Psychology, 51(6), 1173-1182.

Baumeister, R. F. (1999). Self-concept, self-esteem, and identity. In V. J. Derlega, B. A. Winstead, \& W. H. Jones (Eds.), Nelson-Hall series in psychology. Personality: Contemporary theory and research (pp. 339-375). Chicago, IL, US: Nelson-Hall Publishers.

Bock, G., Zmud, R., Kim, Y., \& Lee, J. (2005). Behavioral Intention Formation in Knowledge Sharing: Examining the Roles of Extrinsic Motivators, SocialPsychological Forces, and Organizational Climate. MIS Quarterly, 29(1), 87-111.

Bolisani, E., \& Bratianu, C. (2018). The elusive definition of knowledge. In Bolisani, E. and Bratianu, C. (eds.). Emergent knowledge strategies: Strategic thinking in knowledge management (pp. 1-22). Cham: Springer International Publishing. 
Chattopahyay, P., \& George, E. (2001). Examining the effects of work externalization through the lens of social identity theory. Journal of Applied Psychology, 86(4), 781788.

Chaudhary, R., \& Panda, C. 2018. Authentic leadership and creativity. International Journal of Productivity and Performance Management, 67(9), 2071-2088.

Davenport, T. H., \& Prusak, L. (1998). Working Knowledge: How Organizations Manage What They Know. Harvard Business School Press, Boston.

De Cremer, D., van Knippenberg, B., van Knippenberg, D., Mullenders, D., \& Stinglhamber, F. (2005). Rewarding Leadership and Fair Procedures as Determinants of Self-Esteem. Journal of Applied Psychology, 90(1), 3-12.

De Meuse, K., Bergmann, T., \& Lester, S. (2001). An investigation of the relational component of the psychological contract across time, generation, and employment status. Journal of Managerial Issues, 13(1), 102-118.

Dong, G., Gia Liem, C., \& Grossman, M. (2010). Knowledge-sharing intention in Vietnamese organizations. VINE, 40(3/4), 262-276.

Dong, Y., Bartol, K. M., Zhang, Z. X., \& Li, C. (2017). Enhancing employee creativity via individual skill development and team knowledge sharing: Influences of dual-focused transformational leadership. Journal of Organizational Behavior, 38(3), 439-458.

Edú-Valsania, S., Moriano, J., \& Molero, F. (2016). Authentic leadership and employee knowledge sharing behavior. Leadership \& Organization Development Journal, 37(4), 487-506.

Elloy, D. (2005). The influence of super leader behaviors on organization commitment, job satisfaction and organization self-esteem in a self-managed work team. Leadership \& Organization Development Journal, 26 (2), 120-127.

Engelbrecht, A., Heine, G., \& Mahembe, B. (2017). Integrity, ethical leadership, trust and work engagement. Leadership \& Organization Development Journal, 38(3), 368-379.

Eppler, M. J., \& Sukowski, O. (2000). Managing team knowledge: core processes, tools and enabling factors. European Management Journal, 18(3), 334-341.

Fornell, C., \& Larcker, D.F. (1981). Evaluating structural equation models with unobservable variables and measurement error. Journal of Marketing Research, 18(1), 39-50.

Frost, J., \& Morner, M. (2010). Overcoming knowledge dilemmas: governing the creation, sharing and use of knowledge resources. International Journal of Strategic Change Management, 2(2/3), 172-199.

Fullwood, R., Rowley, J., \& McLean, J. (2019). Exploring the factors that influence knowledge sharing between academics. Journal of Further and Higher Education, 43(8), 1051-1063.

Gardner, D. G., \& Pierce, J. L. (2016). Organization-based self-esteem in work teams. Group Processes \& Intergroup Relations, 19(3), 394-408.

Gardner, W. L., Avolio, B. J., Luthans, F., May, D. R., \& Walumbwa, F. O. (2005). Can you see the real me? A self-based model of authentic leader and follower development. The Leadership Quarterly,16(3), 343-372.

Gardner, W. L., Cogliser, C. C., Davis, K. M., \& Dickens, M. P. (2011). Authentic leadership: A review of the literature and research agenda. The Leadership Quarterly, 22(6), 1120-1145.

George, B. (2003). Authentic Leadership: Rediscovering the Secrets to Creating Lasting Value. San Francisco, CA: Jossey-Bass.

Gupta, B., Agarwal, A., Samaria, P., Sarda, P., \& Bucha, R. (2012). Organizational Commitment and Psychological Contract in Knowledge Sharing Behavior. Indian Journal of Industrial Relations, 47(4), 737-749. 
Gill, C., \& Caza, A. (2018). An Investigation of Authentic Leadership's Individual and Group Influences on Follower Responses. Journal of Management, 44(2), 530-554.

Hair, J.F, Black, W.C., Babin, B.J., Anderson, R.E., and Tatham, R.L. (2006). Multivariate Data Analysis, 6th ed. New Jersey: Prentice Hall.

Han, S., Seo, G., Yoon, S., \& Yoon, D. (2016). Transformational leadership and knowledge sharing. Journal of Workplace Learning, 28(3), v130-149.

Hannah, S., Avolio, B., \& Walumbwa, F. (2011). Relationships between Authentic Leadership, Moral Courage, and Ethical and Pro-Social Behaviors. Business Ethics Quarterly, 21(4), 555-578.

Heck, A. K., Bedeian, A. G., \& Day, D. V. (2005). Mountains out of molehills? Tests of the mediating effects of self-esteem in predicting workplace complaining. Journal of Applied Social Psychology, 35(11), 2262-2289.

Henderson, S., Byrne, G. O., \& Duncan-Jones, P. (1981). Neurosis and social environment. Sidney, Australia: Academic Press.

Henttonen, K., Kianto, A., \& Ritala, P. (2016). Knowledge sharing and individual work performance: an empirical study of a public sector organization. Journal of Knowledge Management, 20(4), 749-768.

Hobfoll, S. E. (1985). Personal and social resources and the ecology of stress resistance. In P. Shaver (Ed.), Review of personality and social psychology (Vol. 6, pp. 265-290). Beverly Hills, CA: Sage.

Hobfoll, S.E. (1989). Conservation of resources: a new approach at conceptualizing stress. American Psychologist, 44(3), 513-524.

Holste, J., \& Fields, D. (2010). Trust and tacit knowledge sharing and use. Journal of Knowledge Management, 14(1), 128-140.

Hu, L. T., \& Bentler, P. M. (1999). Cutoff criteria for fit indexes in covariance structure analysis: Conventional criteria versus new alternatives. Structural Equation Modeling, 6(1), 1-55.

Ibragimova, B. (2007). Propensity for knowledge sharing: An organizational justice perspective, Pro-Quest Information \& Learning. USA: University of North Texas.

Javed, B., Rawwas, M., Khandai, S., Shahid, K., \& Tayyeb, H. (2018). Ethical leadership, trust in leader and creativity: The mediated mechanism and an interacting effect. Journal of Management \& Organization, 24(3), 388-405.

Kernis, M. H. (2003). Toward a conceptualization of optimal self-esteem. Psychological Inquiry, 14(1), 1-26.

Kim, S., Lee, S., \& Yun, S. (2016). Abusive supervision, knowledge sharing, and individual factors. Journal of Managerial Psychology, 31(6), 1106-1120.

Knights, J.A., \& Kennedy, B.J. (2005). Psychological Contract Violation: Impacts on Job Satisfaction and Organizational Commitment among Australian Senior Public Servants. Applied H.R.M. Research, 10(2), 57-72.

Korman, A. K. (1970). Toward a hypothesis of work behavior. Journal of Applied Psychology, 54(1, Pt.1), 31-41.

Li, Y.B., Wu, T.J., \& Lin, C.P. (2017). Authentic leadership and knowledge sharing in stateowned enterprises of China: An Empirical Study. Journal of Interdisciplinary Mathematics, 20(3), 881-894.

Liang, S. G. (2017). Linking leader authentic personality to employee voice behavior: a multilevel mediation model of authentic leadership development. European Journal of Work and Organizational Psychology, 26(3), 434-443.

Lin, N., Jang, J., \& Roberts, K. R. (2018). Are employees with higher organization-based self-esteem less likely to quit? A moderated mediation model. International Journal of Hospitality Management, 73(2018), 116-124. 
Luthans, F., \& Avolio, B. J. (2009). The "point" of positive organizational behavior. Journal of Organizational Behavior, 30(2), 291-307.

Ma, Y., Cheng, W., Ribbens, B. A., \& Zhou, J. (2013). Linking ethical leadership to employee creativity: Knowledge sharing and self efficacy as mediators. Social Behavior and Personality: An International Journal, 41(9), 1409-1419.

Macneil, I.R. (1985). Relational contract: What we do and do not know. Wisconsin Law Review, 45(4), 483-525.

Martins, E.C., \& Martins, N. (2011). The role of organizational factors in combating tacit knowledge loss in organizations. Southern African Business Review, 15(1), 49-69.

Millward, L. J., \& Hopkins, L. J. 1998. Psychological contracts, organizational and job commitment. Journal of Applied Social Psychology, 28(16), 1530-1556.

Nielsen, M. B., Eid, J., Mearns, K., \& Larsson, G. (2013). Authentic leadership and its relationship with risk perception and safety climate. Leadership \& Organization Development Journal, 34(4), 308-325.

Nonaka, I. (1994). A Dynamic Theory of Organizational Knowledge Creation. Organization Science, 5(1), 14-37.

Nonaka, I., \& Konno, N. (1998). The Concept of "Ba": Building a Foundation for Knowledge Creation. California Management Review, 40(3), 40-54.

Nonaka, I., \& Takeuchi, H. (1995). The Knowledge-Creating Company. Oxford University Press, New York, NY.

Norman, S., Gardner, D., \& Pierce, J. (2015). Leader roles, organization-based self-esteem, and employee outcomes. Leadership \& Organization Development Journal, 36(3), 253270.

Oh, J., Cho, D., \& Lim, D. (2018). Authentic leadership and work engagement: the mediating effect of practicing core values. Leadership \& Organization Development Journal, 39(2), 276-290.

Okah, J., Teye, V., \& Shoniregun, C. (2011). E-learning and knowledge management: bridging technological gaps can bridge knowledge gaps in Ghanaian universities. Ubiquitous Learning: An International Journal, 3(4), 173-184.

Pan, X., Qin, Q., \& Gao, F. (2014). Psychological ownership, organization-based self-esteem and positive organizational behaviors. Chinese Management Studies, 8(1), 127-148.

Pierce, J. L., \& Gardner, D. G. (2004). Self-Esteem Within the Work and Organizational Context: A Review of the Organization-Based Self-Esteem Literature. Journal of Management, 30(5), 591-622.

Pierce, J. L., Gardner, D. G., Cummings, L. L., \& Dunham, R. B. (1989). Organization-based self-esteem: Construct definition, measurement, and validation. Academy of Management Journal, 32(3), 622-648.

Pierce, J.L., Gardner, D.G., \& Crowley, C. (2016). Organization-based self-esteem and wellbeing: empirical examination of a spillover effect. European Journal of Work and Organizational Psychology, 25(2), 181-199.

Podsakoff, P. M., MacKenzie, S. B., Lee, J.-Y., \& Podsakoff, N. P. (2003). Common method biases in behavioral research: A critical review of the literature and recommended remedies. Journal of Applied Psychology, 88(5), 879-903.

Politis, J. (2001). The relationship of various leadership styles to knowledge management. Leadership \& Organization Development Journal, 22(8), 354-364.

Raja, U., Johns, G., \& Ntalianis, F. 2004. The Impact of Personality on Psychological Contracts. Academy of Management Journal, 47(3), 350-367.

Ribeiro, N., Duarte, A. P., Filipe, R., \& Torres de Oliveira, R. (2019). How Authentic Leadership Promotes Individual Creativity: The Mediating Role of Affective Commitment. Journal of Leadership and Organizational Studies, Online First. 
Rousseau, D. M. (1989). Psychological and Implied Contracts in Organizations. Employee Responsibilities and Rights Journal, 2(2), 121-139.

Rousseau, D. M. (1990). New hire perceptions of their own and their employer's obligations: A study of psychological contracts. Journal of Organizational Behavior 11(5), 389-400.

Rousseau, D. M. (1995). Psychological contracts in organizations: Understanding written and unwritten agreements. Thousand Oaks, CA: Sage.

Rousseau, D. M., \& McLean Parks, J. (1993). The contracts of individuals and organizations. In Research in Organizational Behavior, edited by L. L. Cummings, and B. M. Staw, Vol. 15: 1-47. Greenwich: JAI Press.

Semedo, A. S., Coelho, A., \& Ribeiro, N. (2017). Authentic leadership and creativity: The mediating role of happiness. International Journal of Organizational Analysis, 25(3), $395-412$.

Singh, S. (2008). Role of leadership in knowledge management: a study. Journal of Knowledge Management, 12(4), 3-15.

Srivastava, A., Bartol, K., \& Locke, E. (2006). Empowering Leadership in Management Teams: Effects on Knowledge Sharing, Efficacy, and Performance. The Academy of Management Journal, 49(6), 1239-1251.

Steiger, J. H. (1990). Structural Model Evaluation and Modification: An Interval Estimation Approach. Multivariate Behavioral Research, 25(2), 173-180.

Stenius, M., Hankonen, N., Ravaja, N., \& Haukkala, A. (2016). Why share expertise? A closer look at the quality of motivation to share or withhold knowledge. Journal of Knowledge Management, 20(2), 181-198.

Tabachnick, B. G., \& Fidell, L. S. (2013). Using Multivariate Statistics (6th ed.). Boston, MA Pearson.

Tang, L.P., Singer, M., \& Roberts, S. (2000). Employees' perceived organizational instrumentality: an examination of the gender differences. Journal of Managerial Psychology, 15(5), 378-406.

Titi Amayah, A. (2013). Determinants of knowledge sharing in a public sector organization. Journal of Knowledge Management, 17(3), 454-471.

Van Dyne, L., \& Pierce, J. L. (2004). Psychological ownership and feelings of possession: three field studies predicting employee attitudes and organizational citizenship behavior. Journal of Organizational Behavior, 25(4), 439-459.

Walumbwa, F. O., Avolio, B. J., Gardner, W. L., Wernsing, T. S., \& Peterson, S. (2008). Authentic leadership: Development and validation of a theory-based measure. Journal of Management, 34(1), 89-126.

Wang, L., Huang, J., Chu, X., \& Wang, X. (2010). A multilevel study on antecedents of manager voice in Chinese context. Chinese Management Studies, 4(3), 212-230.

Wang, S., \& Noe, R.A. (2010). Knowledge Sharing: A Review and Directions for Future Research. Human Resource Management Review, 20(2), 115-131.

Xue, Y., Bradley, J., \& Liang, H. (2011). Team climate, empowering leadership, and knowledge sharing. Journal of Knowledge Management, 15(2), 299-312.

Zhang, X., \& Bartol, K. M. (2010). Linking empowering leadership and employee creativity: The influence of psychological empowerment, intrinsic motivation, and creative process engagement. The Academy of Management Journal, 53(1), 107-128. 